\title{
Water Quality Assessment Using Multivariate Statistical Methods-A Case Study: Melen River System (Turkey)
}

\author{
Rabia Koklu • Bulent Sengorur • Bayram Topal
}

Received: 4 December 2008 / Accepted: 3 July 2009 /

Published online: 23 July 2009

(C) Springer Science+Business Media B.V. 2009

\begin{abstract}
This study is focused on water quality of Melen River (Turkey) and evaluation of 26 physical and chemical pollution data obtained five monitoring stations during the period 1995-2006. It presents the application of multivariate statistical methods to the data set, namely, principal component and factor analysis (PCA/FA), multiple regression analysis (MRA) and discriminant analysis (DA). The PCA/FA was employed to evaluate the high-low flow periods correlations of water quality parameters, while the principal factor analysis technique was used to extract the parameters that are most important in assessing high-low flow periods variations of river water quality. Latent factors were identified as responsible for data structure explaining $72-97 \%$ of the total variance of the each data sets. PCA/FA was supported with multiple regression analysis to determine the most important parameter in each factor. It examines the relation between a single dependent variable and a set of independent variables to best represent the relation in the each factor. Obtained important parameters provided us to determine the major pollution sources in Melen River Basin. So factors are conditionally named soil structure and erosion, domestic, municipal and industrial effluents, agricultural activities (fertilizer, irrigation water and livestock wastes), atmospheric deposition and seasonal effects factors. DA applied the data set to obtain the parameters responsible for temporal and spatial variations. Assessment of high-low flow period changes in surface water quality is an important aspect for evaluating temporal and spatial variations of
\end{abstract}

R. Koklu $(\varangle) \cdot$ B. Sengorur

Environmental Engineering Department, Sakarya University, Esentepe Campus, 54187 Sakarya, Turkey

e-mail:rkoklu@sakarya.edu.tr

B. Topal

Industrial Engineering Department, Sakarya University,

Esentepe Campus, 54187 Sakarya, Turkey 
river pollution. The aim of this study is illustration the usefulness of multivariate statistical analysis for evaluation of complex data sets, in Melen River water quality assessment identification of factors and pollution sources, for effective water quality management determination the spatial and temporal variations in water quality.

Keywords Surface water quality • Multivariate statistical analysis • Parameter reduction $\cdot$ Melen River

\section{Introduction}

The surface water quality is a matter of serious concern today. Rivers due to their role in carrying off the municipal and industrial wastewater and run-off from agricultural land in their vast drainage basins are among the most vulnerable water bodies to pollution (Singh et al. 2005). Flow in rivers is a function of many factors including precipitation, surface runoff, interflow, groundwater flow and pumped inflow and outflow. Seasonal variations of these factors have a strong effect on flow rates and hence on the concentration of pollutants in the river water (Vega et al. 1998). It is imperative to prevent and control the rivers pollution and to have reliable information on the quality of water for effective management (Singh et al. 2005). For effective pollution control and water resource management, it is required to interpreting a large number of water quality data. Results in a huge and complex data matrix comprised of a large number of physico-chemical parameters, which are often difficult to interpret and draw meaningful conclusions (Dixon and Chiswell 1996).

Factor analysis, which includes principal component analysis (PCA) is a very powerful technique applied to reduce the dimensionality of a data set consisting of a large number of inter-related variables, while remaining as much as possible the variability present in data set. This reduction is achieved by transforming the data set into a new set of variables, the principal components (PCs), which are orthogonal (non-correlated) and are arranged in decreasing order of importance (Panda et al. 2006).

Principal component analysis provides information on the most meaningful parameters, which describe whole data set rendering data reduction with minimum loss of original information (Singh et al. 2004). PCA has allowed the identification of a reduced number of latent factors with pollution sources such as spatial (pollution from anthropogenic origin) and temporal (seasonal and climatic) sources of variation affecting quality and hydrochemistry of river water have been differentiated and assigned to polluting sources (Shrestha and Kazama 2007; Simeonov et al. 2003; Kowalkowski et al. 2006; Pekey et al. 2004; Vega et al. 1998). At the same time PCA has allowed the explaining of related parameters by only one factor (Boyacioğlu and Boyacıŏlu 2006; Kannel et al. 2007; Kottı et al. 2005; Kowalkowski et al. 2006; Sengörür and İsa 2001; Singh et al. 2004) and exposing of the important factor responsible for seasonal changes in river water quality (Ouyang 2005; Ouyang et al. 2006).

Multiple Regression examines the relation between a single dependent variable and a set of independent variables to best represent the relation in the population. 
It was used to investigate relationships between water quality parameters (physicochemical and biological) and landscape characteristics (Amiri and Nakane 2009; Sliva and Williams 2001; Wang 2001; Singh et al. 2005) and to investigate between water quality and pathogen indicators (Mallin et al. 2000; Crowther et al. 2001).

Discriminant Analysis is a statistical method which obtains to discriminate variables between two or more naturally occurring groups. DA was used for identification of water quality variables responsible for spatial and temporal variations in river water quality (Shrestha and Kazama 2007; Singh et al. 2004, 2005). Kowalkowski et al. (2006) used DA to classify and, thus, to confirm the groups found by means of the cluster analysis.

In the present study, a large data matrix, obtained during an 11-year (1995-2006) monitoring program, is subjected to PCA/FA, MRA and DA techniques. The aims of this study are to demonstrate the application of the data reduction techniques (PCA/FA) to evaluate the importance of various water quality parameters, regression techniques (MRA) to determine the most meaningful parameters responsible for water quality and discriminant techniques (DA) identification of water quality variables responsible for spatial and temporal variations in river water quality.

\section{Materials and Methods}

\subsection{Study Area}

The Melen River is in the north of the Turkey which has got a complex river system that supports a variety of uses, including irrigation systems in agricultural lands, drinking water and several different industries wastewater. The return flow from all these users is directly discharged into the river. The Big Melen River receives some tributary streams, Aksu Stream, Ugur Stream, the Small Melen River and Asar Stream. Aksu Stream, Ugur Stream and Asar Stream contribute the Small Melen River and then, the Small Melen River converges with Big Melen River a derivation canal before discharging into Efteni Lake. River System calls the Big Melen River after Efteni Lake. The Melen River Basin covers about 2,317 $\mathrm{km}^{2}$. It flows into the Black Sea with $48.2 \mathrm{~m}^{3} / \mathrm{s}$ average flow according to measurement results between 1995-2006. Düzce City (Turkey) is the biggest urban settlement in the Melen River Basin. Important pollution sources in basin are domestic, industrial wastewater and agricultural run-off. The Melen River is also affected by non-point sources of pollution including fertilizers from farm effluents, livestock wastes and septic tanks effluents or point sources of pollution including domestic, some industries wastewater discharges and treatment plant effluents. Asar Stream drainage basin has intensive industrial activities and daily residence plants effluents. The Small Melen River receives sewage wastewater discharges from Düzce City after wastewater is treated, livestock wastes and run-off from dumps. The other towns in the basin have no sewage treatment plant. Basin has density agricultural activity and also intensive forest cover (at high regions). Therefore, mineral concentration comes from the alluvion soil structure (gravel, sand, clay, silt) (Düzce Environment State Report 2007). 
The Melen River System Drainage Basin and Sample Points are shown in Fig. 1. The data for five sample points were obtained from monitoring programs of Government Water Association in Ankara, Turkey.

\subsection{Measurement Stations and Parameters}

River water data were obtained at high and low flow periods from at three different sites on river and at two different sites on its tributaries, namely Small Melen Pasakonagi (1KMP), Big Melen Pakmaya (2BMP), Big Melen Aydogan (3BMA) and Aksu Stream (4AC), Ugur Stream (5US) (Fig. 1) once 2-3 month during a period of 11 years (1995-2006).

The data were obtained from by analyzing of Government Water Association monitoring program. $\mathrm{pH}$, temperatures $\left(\mathrm{T},{ }^{\circ} \mathrm{C}\right)$, electrical conductivity $(\mathrm{EC}$, $\mathrm{mohm} / \mathrm{cm}$ ), Suspended Solids (SS, mg L ${ }^{-1}$ ), turbidity (turb, NTU), flow (Q, $\mathrm{m}^{3} \mathrm{sn}^{-1}$ ), total alkalinity (M-Alk, mg L ${ }^{-1}$ ), total hardness (T-Hard, $\mathrm{mg} \mathrm{L}^{-1}$ ), total dissolved solids (TDS, $\mathrm{mg} \mathrm{L}^{-1}$ ), dissolved oxygen (DO, $\mathrm{mg} \mathrm{L}^{-1}$ ), 5-days biochemical oxygen demand $\left(\mathrm{BOD}_{5}, \mathrm{mg} \mathrm{L}^{-1}\right)$, chemical oxygen demand (COD, $\mathrm{mg} \mathrm{L}^{-1}$ ), ammonium nitrogen $\left(\mathrm{NH}_{4}-\mathrm{N}, \mathrm{mg} \mathrm{L}^{-1}\right)$, nitrate nitrogen $\left(\mathrm{NO}_{3}-\mathrm{N}, \mathrm{mg} \mathrm{L}^{-1}\right)$, nitrite nitrogen $\left(\mathrm{NO}_{2}-\mathrm{N}, \mathrm{mg} \mathrm{L}{ }^{-1}\right)$, chloride $\left(\mathrm{Cl}^{-}, \mathrm{mg} \mathrm{L}{ }^{-1}\right)$, sulphate $\left(\mathrm{SO}_{4}^{2-}, \mathrm{mgL}^{-1}\right)$, phosphate $\left(\mathrm{PO}_{4}^{3-}, \mathrm{mg} \mathrm{L}^{-1}\right)$, sodium $\left(\mathrm{Na}^{+}, \mathrm{mg} \mathrm{L}^{-1}\right)$, potassium $\left(\mathrm{K}^{+}, \mathrm{mg} \mathrm{L} \mathrm{L}^{-1}\right)$, calcium $\left(\mathrm{Ca}^{2+}\right.$,

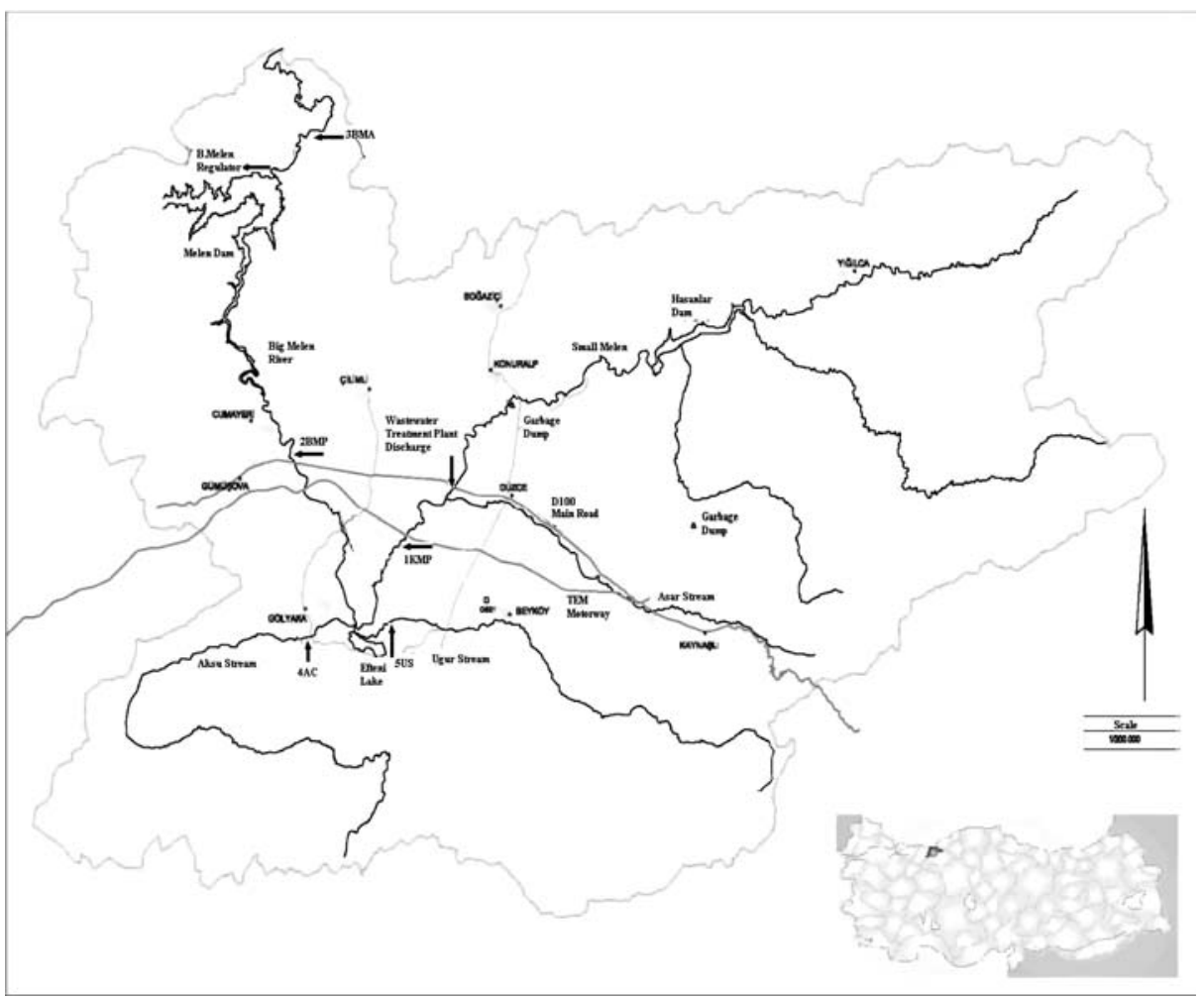

Fig. 1 Big Melen River system drainage basin and sample points 
$\left.\mathrm{mg} \mathrm{L}{ }^{-1}\right)$, magnesium $\left(\mathrm{Mg}^{2+}, \mathrm{mg} \mathrm{L}^{-1}\right)$, boron $\left(\mathrm{B}^{3+}, \mathrm{mg} \mathrm{L}^{-1}\right)$, ferrous $\left(\mathrm{Fe}^{2+}, \mathrm{mg} \mathrm{L}^{-1}\right)$, manganese $\left(\mathrm{Mn}^{2+}, \mathrm{mg} \mathrm{L}^{-1}\right)$ and fecal streptococcus (F-Strip, MPN/100 mL) and total coliform (T-Coli, MPN/100 mL), Escherichia coliform (E-Coli, MPN/100 mL) were analyzed by laboratory of Government Water Association using standard methods (APHA-AWWA-WPCF 1999). The basic statistics of the 11 years data set on river water quality is summarized Tables 1 and 2 .

\subsection{Data Analysis and Statistical Methods}

In this study, the water quality parameters were grouped in two different periods (wet and dry season) by investigating the months of rainy-dry and high-low flow. They were analyzed and their mean values and standard deviations are summarized in Tables 1 and 2. Before the applying of the multivariate statistical techniques, experimental data were normalized within the range 0.1 to 0.9 in order to avoid misclassification due to wide differences in data dimensionality. tends to minimize the influence of difference of variance of variables and eliminates the influence of different units of measurement and renders the data dimensionless.

$$
x_{i}=0.8 \frac{\left(x-x_{\min }\right)}{\left(x_{\max }-x_{\min }\right)}+0.1
$$

where $x_{i}$ is the normalized value of a certain parameter, $x$ is the measured value for this parameter, $x_{\min }$ and $x_{\max }$ are the minimum and maximum values in the database for this parameter, respectively (Dogan et al. 2009).

The water quality data were subjected to different multivariate statistical techniques to explore the parameters which were responsible of the water quality variation in different season. PCA/FA was applied to the normalized data of each station for two periods. Varimax rotating method was used for applying PCA/FA. Corresponding $\mathrm{f}_{\mathrm{Hij}}$ (f: Factor; H: High flow period; i: Station number; $\mathrm{j}$ : Factor number) and $\mathrm{f}_{\mathrm{Lij}}$ (f: Factor; L: Low flow period; i: Station number; j: Factor number), variable loadings and explained variance are determined. Liu et al. (2003) classified the factor loadings as 'strong', 'moderate' and 'weak, corresponding to absolute loading values of $>0.75,0.75-0.50$ and $0.50-0.30$, respectively. FA/PCA results were exposed to MRA. Multiple regression analysis examines the relation between a single dependent variable and a set of independent variables to best represent the relation in the each factor. MRA models were used to determine the most meaningful parameters responsible for the water quality. DA was used for identification of water quality variables responsible for spatial and temporal variations in river water quality. Discriminant functions related to the parameters of temporal and spatial variations were obtained. All the mathematical and statistical computations were made using Excel 2003 and SPSS 13.0.

\subsubsection{Factor Analysis/Principal Component Analysis (FA/PCA)}

Principal Component Analysis is a data analysis method focused on a particular collection of variables. Consider the form of the first principal component. The score for individual $\mathrm{i}$ on component, $c_{i 1}$, uses weights $w_{11}, \ldots \ldots, w_{p 1}$ in the linear combination

$$
c_{i 1}=y_{i 1} w_{11}+y_{i 2} w_{22}+\cdots+y_{i p} w_{p 1}
$$




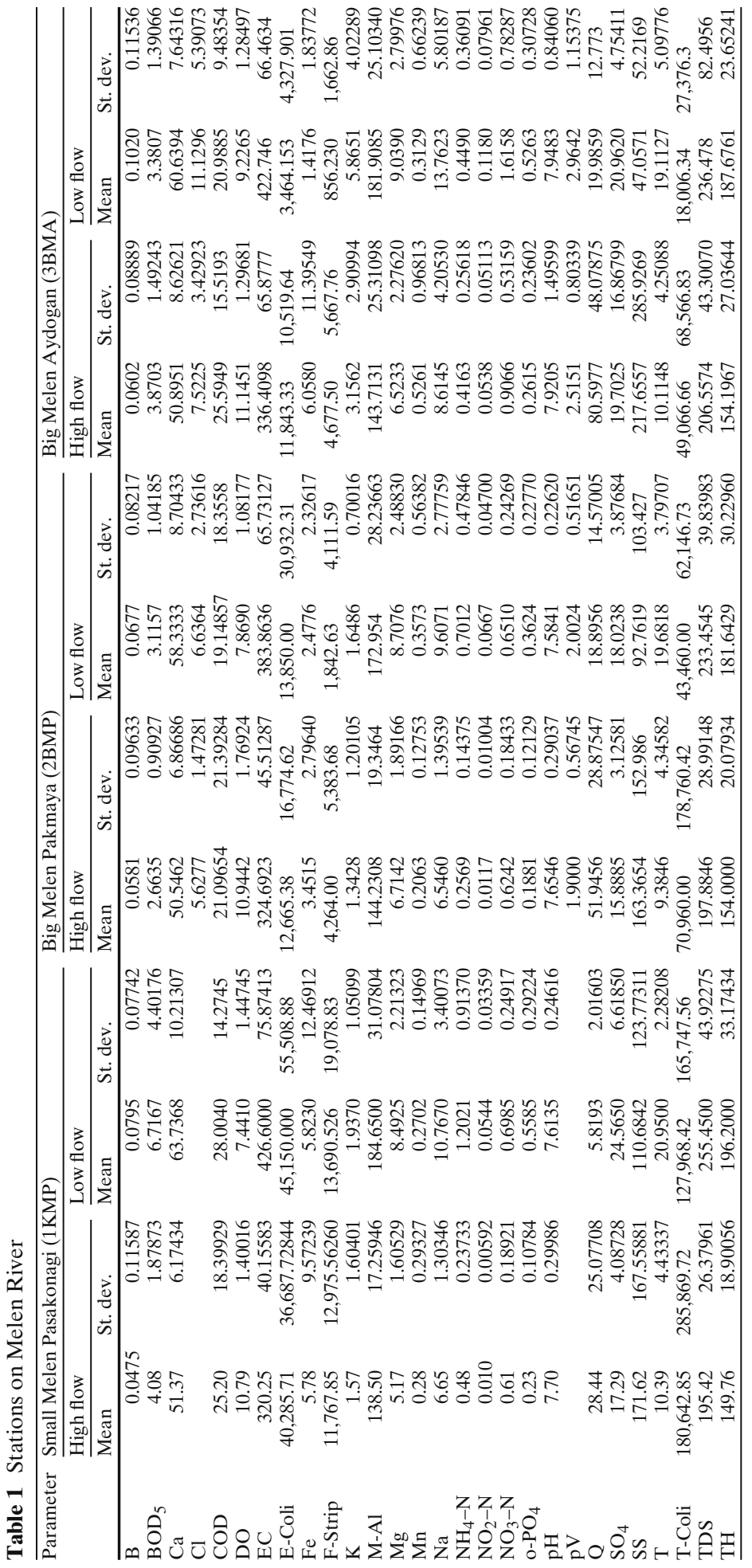




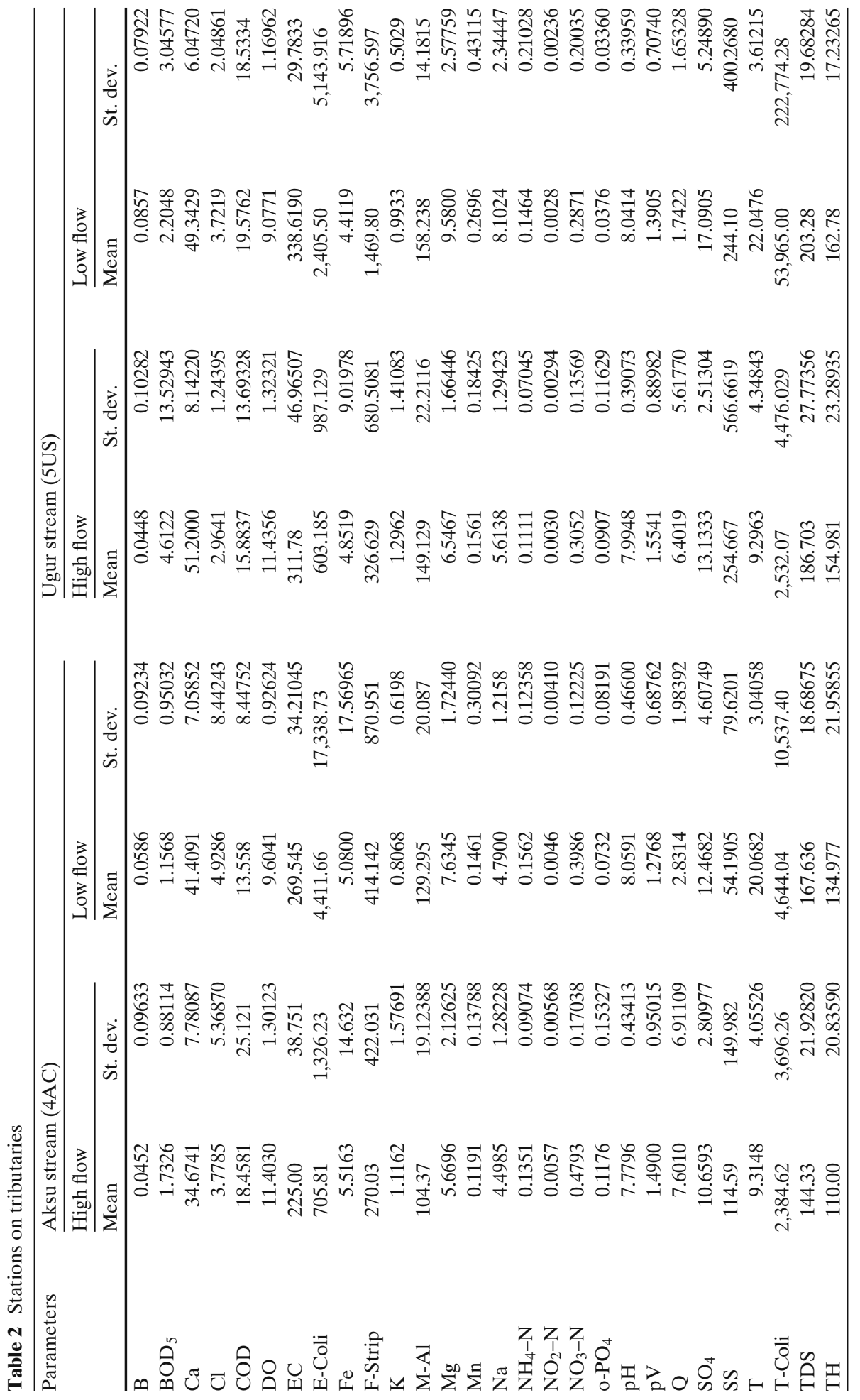


This linear combination is chosen so that the sum of squares of $c_{1}$ is as large as possible subject to the condition that $w_{11}^{2}+\ldots \ldots \ldots+w_{p 1}^{2}=1$. The second principal component is another linear combination of $y_{j}$

$$
c_{i 2}=y_{i 1} w_{12}+y_{i 2} w_{22}+\cdots+y_{i p} w_{p 2}
$$

where the variance $c_{2}$ is the maximal, subject to the conditions that $\operatorname{corr}\left(\mathrm{c}_{1}, \mathrm{c}_{2}\right)=0$ and that $w_{12}^{2}+\ldots \ldots \ldots+w_{p 2}^{2}=1$. The criterion of summarizing the information in $p$ variables by a few components is valuable as a means of reducing the number of variables needed in an analysis (Tinsley and Brown 2000).

FA follows PCA. The main purpose of FA is to reduce the contribution of less significant variables to simplify even more of the data structure coming from PCA. This purpose can be achieved by rotating the axis defined by PCA, according to well established rules, and constructing new variables, also called varifactors (VF). PCA of the normalized variables was performed to extract significant PCs and to further reduce the contribution of variables with minor significance; these PCs were subjected to varimax rotation (raw) generating VFs (Brumelis et al. 2000; Singh et al. 2004, 2005).

The FA can be expressed as:

$$
y_{j i}=f_{j 1} z_{i 1}+f_{j 2} z_{i 2}+\cdots+f_{j m} z_{i m}+e_{i j}
$$

where $\mathrm{y}$ is the measured variable, $\mathrm{f}$ is the factor loading, $\mathrm{z}$ is the factor score, e the residual term accounting for errors or other source of variation, $i$ the sample number and $\mathrm{m}$ the total number of factors (Tinsley and Brown 2000).

\subsubsection{Multiple Regression Analysis (MRA)}

Multiple regression analysis is a statistical tool for understanding the relationship between two or more variables. Multiple regression examines the relation between a single dependent variable and a set of independent variables to best represent the relation in the population. The technique is used for both predictive and explanatory purposes within experimental or nonexperimental designs (Tinsley and Brown 2000). When there are an arbitrary number of explanatory variables, the linear regression model takes the following form:

$$
Y=\beta_{0}+\beta_{1} \cdot X_{1}+\beta_{2} \cdot X_{2}+\ldots \ldots \ldots+\beta_{m} \cdot X_{m}+e_{i j}
$$

where $\mathrm{Y}$ represents the dependent variable and $X_{1} \ldots X_{m}$ represent the different independent variables, $\beta_{0}, \ldots \ldots \ldots, \beta_{m}$ represent the regression coefficient and $e$ represents the random error (Freund and Wilson 1998). The error term e represents the collective unobservable influence of any omitted variables. In a linear regression each of the terms being added involves unknown parameters, which are estimated by "fitting" the equation to the data using least-squares.

\subsubsection{Discriminant Analysis (DA)}

Discriminant Analysis is a statistical method which obtains to discriminate variables between two or more naturally occurring groups. It calculates mathematical weights for scores on each discriminator variable that reflect the degree to which scores 
on that variable differ among the groups being discriminated. It forms one or more weighted linear combinations of discriminator variables called discriminant functions. Each discriminant function has the general form:

$$
D=a+b_{1} \cdot X_{1}+b_{2} \cdot X_{2}+\ldots \ldots \ldots+b_{P} \cdot X_{P}
$$

where $\mathrm{D}$ is the discriminant score ( $\mathrm{z}$ score), $\mathrm{a}$ is the $\mathrm{Y}$-intercept of the regression line, $\mathrm{b}$ is the discriminant function coefficient, $\mathrm{X}$ is the discriminator variable raw score, and $\mathrm{p}$ is the number of discriminator variable (Tinsley and Brown 2000).

\section{Results and Discussions}

\subsection{High Flow Period}

PCA of the 26 parameters constituted seven PCs explaining about $85.05 \%$ of the total variance at the $1 \mathrm{KMP}$ Station water quality data set for high flow period as seen in Table 3. $\mathrm{f}_{\mathrm{H} 11}$ has strong positive loadings on $\mathrm{Ca}^{2+}, \mathrm{M}-\mathrm{Al}, \mathrm{TH}, \mathrm{EC}$, TDS; negative loadings on $\mathrm{Q}$ and moderate negative loadings on $\mathrm{Fe}^{2+}$, COD and positive loadings on E-Coli. It was formed $25.84 \%$ of total variance. Flow must be measured in water quality monitoring program. $\mathrm{f}_{\mathrm{H} 12}$ accounting for $12.95 \%$ of total variance has strong positive loadings on $\mathrm{K}^{+}$, F-Strip, o- $\mathrm{PO}_{4}{ }^{3+}$ and moderate loadings on $\mathrm{B}^{3+}, \mathrm{SO}_{4}^{2-}$ and weak loadings on $\mathrm{Na}$ according to PCA results. $\mathrm{f}_{\mathrm{H} 13}$ accounting for $10.05 \%$ of total variance has strong positive loadings on $\mathrm{NO}_{2}-\mathrm{N}, \mathrm{NO}_{3}-\mathrm{N}$ and moderate loadings on $\mathrm{BOD}_{5}$; weak loadings on $\mathrm{T}-\mathrm{Coli}, \mathrm{NH}_{4}-\mathrm{N}$ according to PCA results. Whereas, fourth, fifth, sixth and seventh factors accounted for the total variance of $10.80 \% ; 8.761 \%$; $8.936 \%$ and $7.692 \%$, were correlated with DO and T; $\mathrm{pH}$ and $\mathrm{SS} ; \mathrm{Mg}^{2+}$ and $\mathrm{Mn}^{2+}$ respectively.

When FA/PCA and MRA were investigated together, TH $98 \%$ or TDS and $\mathrm{COD}$, E-Coli could explain the $\mathrm{f}_{\mathrm{H} 11}$. This factor represents soil structure and subsequent run-off which can be interpreted as a mineral component of the river and anthropogenic facilities. This clustering of variables points to a common origin for these minerals likely from dissolution of limestone and gypsum soils (Vega et al. 1998). It may be noted that gypsum is widely used as soil modifier in the river catchments (Singh et al. 2004). MRA was applied the data, $66 \%$ of parameters in $\mathrm{f}_{\mathrm{H} 12}$ were classified correctly by using $\mathrm{o}-\mathrm{PO}_{4}{ }^{3-}$. We say that $\mathrm{o}-\mathrm{PO}_{4}{ }^{3-}, \mathrm{SO}_{4}{ }^{2-}$ and F-Strip could explain the $\mathrm{f}_{\mathrm{H} 12}$ which can be interpreted as agricultural activities such as livestock waste and atmospheric deposition in basin. $55 \%$ of parameters in $\mathrm{f}_{\mathrm{H} 13}$ were classified correctly by using $\mathrm{NO}_{2}-\mathrm{N}$ and $\mathrm{NH}_{4}-\mathrm{N}$ which can be interpreted as organic contamination mainly from domestic wastewater and run-off from dump. $\mathrm{NO}_{2}-\mathrm{N}$ is usually associated with active biological process influenced by organic pollution. DO $61 \%$ and $\mathrm{T}$ explain the $\mathrm{f}_{\mathrm{H} 14}$ as a seasonal factor; $\mathrm{pH}$ and SS explain the $\mathrm{f}_{\mathrm{H} 15}$ which describes industrial activities; $\mathrm{Mg}^{2+}$ and $\mathrm{Mn}^{2+}$ explain the $\mathrm{f}_{\mathrm{H} 16}$ and $\mathrm{f}_{\mathrm{H} 17}$ factor.

PCA of the 28 parameters constituted five PCs explaining about $85.2 \%$ of the total variance at the $2 \mathrm{BMP}$ Station water quality data set for high flow period as seen in Table $3 . \mathrm{f}_{\mathrm{H} 21}$ explained $30.81 \%$ of total variance and was strong positively contributed 


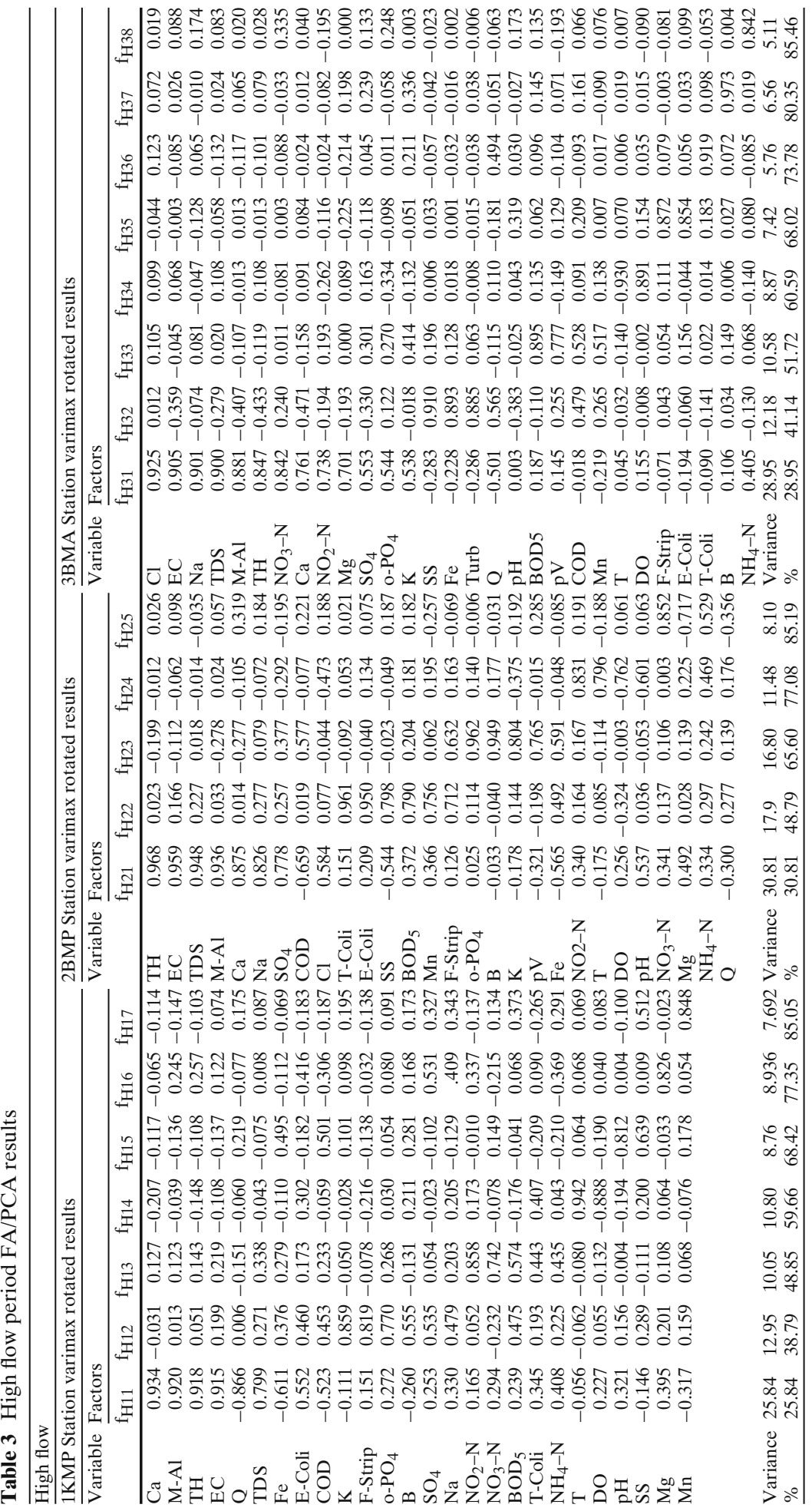


by TH, EC, TDS, M-Al, $\mathrm{Ca}^{2+}, \mathrm{Na}^{+}, \mathrm{SO}_{4}^{2-}$; moderate positively contributed by $\mathrm{Cl}^{-}$ and negatively contributed by COD. $\mathrm{f}_{\mathrm{H} 22}$ explained $17.9 \%$ of total variance and was strong positively contributed by T-Coli, E-Coli, SS, $\mathrm{BOD}_{5}, \mathrm{Mn}^{2+}$; moderate positively contributed by F-Strip. $\mathrm{f}_{\mathrm{H} 23}$ explained $16.8 \%$ of total variance and strong correlated with $\mathrm{o}-\mathrm{PO}_{4}^{3-}, \mathrm{B}^{3+}, \mathrm{K}^{+}, \mathrm{pV}$; moderate correlated with $\mathrm{Fe}^{2+}$. $\mathrm{f}_{\mathrm{H} 24}$ formed $11.48 \%$ of total variance and strong positively correlated with $\mathrm{NO}_{2}-\mathrm{N}$, T; negatively correlated with DO and moderate negatively correlated with $\mathrm{pH}$. $\mathrm{f}_{\mathrm{H} 25}$ accounted for the total variance of $8.1 \%$ and was strong positively contributed by $\mathrm{NO}_{3}-\mathrm{N}$; moderate negatively contributed by $\mathrm{Mg}^{2+}$; moderate positively contributed by $\mathrm{NH}_{4}-$ $\mathrm{N}$ and weak negatively contributed by $\mathrm{Q}$.

FA/PCA and MRA were investigated together and $\mathrm{Ca} 95.6 \%$ and COD, $\mathrm{Na}^{+}$, TDS could explain the $\mathrm{f}_{\mathrm{H} 21}$. This factor represents soil structure which can be interpreted as a mineral component of the river and urban run-off such as industrial, commercial, residential. MRA was applied the data, $86,7 \%$ of parameters in $\mathrm{f}_{\mathrm{H} 22}$ were classified correctly by using T-Coli and SS. $\mathrm{f}_{\mathrm{H} 22}$ represents the bacteriological and anthropogenic pollution such as municipal wastewater and agricultural activities such as livestock wastes. $55.5 \%$ of parameters in $\mathrm{f}_{\mathrm{H} 23}$ were classified correctly by using $\mathrm{o}-\mathrm{PO}_{4}{ }^{3-}$ which can be interpreted as diffuse agricultural activities and point sewage treatment work. Phosphorus absorbs strongly onto soil particles, most of the diffuse load enters the river during run-off events in autumn and winter, under conditions of high river flow (Mainstone and Parr 2002). $\mathrm{Fe}^{2+}$ and $\mathrm{pV}$ can be added the measurement program. $73.6 \%$ of parameters in $\mathrm{f}_{\mathrm{H} 24}$ were classified correctly by using $\mathrm{DO}$ and $\mathrm{pH}$. This factor represents the industrial discharges. $\mathrm{f}_{\mathrm{H} 25}$ was explained by $\mathrm{NO}_{3}-\mathrm{N}, \mathrm{Mg}^{2+}, \mathrm{NH}_{4}-\mathrm{N}, \mathrm{Q}$ according to MRA and this factor represents agricultural activities and atmospheric deposition. Nitrate is more associated with the use of organic and inorganic fertilizers (Maillard and Santos 2008; Vega et al. 1998).

PCA of the 29 parameters constituted eight PCs explaining about $85.46 \%$ of the total variance at the 3BMA Station water quality data set for high flow period as seen in Table 3. $\mathrm{f}_{\mathrm{H} 31}$ has strong positive loadings on $\mathrm{Cl}^{-}, \mathrm{EC}, \mathrm{Na}^{+}$, TDS, M-Al, TH, $\mathrm{NO}_{3}-\mathrm{N}, \mathrm{Ca}^{2+}$ and moderate loadings on $\mathrm{NO}_{2}-\mathrm{N}, \mathrm{Mg}^{2+}, \mathrm{SO}_{4}{ }^{2+}, \mathrm{o}-\mathrm{PO}_{4}{ }^{3-}, \mathrm{K}^{+}$. It was formed $25.95 \%$ of total variance. $\mathrm{f}_{\mathrm{H} 32}$ accounting for $12.18 \%$ of total variance has strong positive loadings on SS, $\mathrm{Fe}^{2+}$, Turb; moderate positive loadings on $\mathrm{Q}$ and weak negative loadings on $\mathrm{pH}$ according to PCA results. $\mathrm{f}_{\mathrm{H} 33}$ accounting for $10,58 \%$ of total variance has strong positive loadings on $\mathrm{BOD}_{5}, \mathrm{pV}$; moderate positive loadings on COD, $\mathrm{Mn}^{2+}$. Whereas, fourth, fifth, sixth, seventh and eight factors accounted for the total variance of $8.87 \% ; 7.42 \% ; 5.76 \% ; 6.56 \%$ and $5.11 \%$, were strong correlated with DO and T; F-Strip, E-Coli; T-Coli; $\mathrm{B}^{3+} ; \mathrm{NH}_{4}-\mathrm{N}$ respectively.

FA/PCA and MRA were investigated together and $\mathrm{Ca}^{2+} 99 \%$ and $\mathrm{SO}_{4}^{2-}, \mathrm{NO}_{2}-\mathrm{N}$, $\mathrm{o}-\mathrm{PO}_{4}^{3-}$ could explain the $\mathrm{f}_{\mathrm{H} 31}$. This factor represents soil structure and agricultural activities such as fertilizer. MRA was applied the data, $92 \%$ of parameters in $\mathrm{f}_{\mathrm{H} 32}$ were classified correctly by using Turb. and Q. This factor explains the erosion from upland areas during rainfall events (Shrestha and Kazama 2007). $\mathrm{f}_{\mathrm{H} 33}$ were classified correctly by using $\mathrm{BOD}_{5}, \mathrm{pV}, \mathrm{COD}, \mathrm{Mn}^{2+}$ which can be interpreted as industrial discharge to the river. $56 \%$ of parameters in $\mathrm{f}_{\mathrm{H} 34}$ were classified correctly by using $\mathrm{DO}$ and $\mathrm{T}$ as a seasonal factor. $\mathrm{f}_{\mathrm{H} 35}$ were classified correctly by using F-Strip and E-Coli which sources are domestic wastewater. $\mathrm{f}_{\mathrm{H} 36}, \mathrm{f}_{\mathrm{H} 37}$ and $\mathrm{f}_{\mathrm{H} 38}$ were explained by $\mathrm{T}$-Coli, $\mathrm{B}, \mathrm{NH}_{4}-\mathrm{N}$ respectively according to MRA. 


\subsection{Low Flow Period}

PCA of the 26 parameters constituted six PCs explaining about $88.96 \%$ of the total variance at the $1 \mathrm{KMP}$ Station water quality data set for low flow period as seen in Table 4. $\mathrm{f}_{\mathrm{L} 11}$ has strong positive loadings on $\mathrm{TH}, \mathrm{EC}, \mathrm{M}-\mathrm{Al}, \mathrm{SO}_{4}^{2-}, \mathrm{Ca}^{2+}, \mathrm{Na}^{+}$, TDS, o- $\mathrm{PO}_{4}^{3-}, \mathrm{NH}_{4}-\mathrm{N}, \mathrm{Mg}^{2+}$ and strong negative loadings on DO; moderate positive loadings on $\mathrm{NO}_{2}-\mathrm{N}$ and weak positive loadings on $\mathrm{K}$. It was formed $38.7 \%$ of total variance. $\mathrm{f}_{\mathrm{L} 12}$ accounting for $20.28 \%$ of total variance has strong positive loadings on F-Strip, E-Coli, T-Coli, COD, SS, $\mathrm{Fe}^{2+}$ according to PCA results. Whereas, third, fourth, fifth and sixth factors accounted for the total variance of $9.68 \% ; 7.99 \% ; 7.13 \%$ and $5.16 \%$, were correlated with $\mathrm{NO}_{3}-\mathrm{N}$ and $\mathrm{Q} ; \mathrm{B}^{3+}$ and $\mathrm{T} ; \mathrm{BOD}_{5}$ and $\mathrm{Mn}^{2+} ; \mathrm{pH}$ respectively.

When FA/PCA and MRA were investigated together, TS $99 \%$ and DO, $\mathrm{K}, \mathrm{NO}_{2}-$ $\mathrm{N}, \mathrm{SO}_{4}^{2-}$ could explain the f1. This factor represents soil structure which can be interpreted as a mineral component of the river. MRA was applied the data and $94 \%$ of parameters in $\mathrm{f}_{\mathrm{L} 12}$ were classified correctly by using SS and COD, F-Strip. We say that $\mathrm{f}_{\mathrm{L} 12}$ can be represents bacteriological and anthropogenic pollution such as municipal wastewater discharge and agricultural activities such as livestock wastes. $\mathrm{NO}_{3}-\mathrm{N}$ and $\mathrm{Q}$ constituted $\mathrm{f}_{\mathrm{L} 13}$ which can be interpreted as agricultural activities such as fertilizer. $\mathrm{B}^{3+}$, $\mathrm{T}$ explains the $\mathrm{f}_{\mathrm{L} 14}$ as soil erosion and seasonal factor; $\mathrm{BOD}_{5}$ and $\mathrm{Mn}^{2+}$ explain the $\mathrm{f}_{\mathrm{L} 15}$ which describes the domestic wastewater factor; $\mathrm{pH}$ explains the $\mathrm{f}_{\mathrm{L} 16}$.

PCA of the 28 parameters constituted five PCs explaining about $97.73 \%$ of the total variance at the $2 \mathrm{BMP}$ Station water quality data set for low flow period as seen in Table $4 . \mathrm{f}_{\mathrm{L} 21}$ explained $40.35 \%$ of total variance and was strong positively contributed by TH, M-Al, EC, SS, $\mathrm{Mg}^{2+}, \mathrm{Ca}^{2+}$, TDS, $\mathrm{Na}^{+}, \mathrm{NO}_{2}-\mathrm{N}, \mathrm{O}_{-} \mathrm{PO}_{4}^{3-}, \mathrm{Cl}^{-}$, $\mathrm{T}$ and moderate positively contributed by $\mathrm{NH}_{4}-\mathrm{N}$. $\mathrm{f}_{\mathrm{L} 22}$ explained $17.29 \%$ of total variance and was strong positively contributed by COD, $\mathrm{Mn}^{2+}, \mathrm{F}-\mathrm{Strip}, \mathrm{Fe}^{2+} \cdot \mathrm{f}_{\mathrm{L} 23}$ explained $10.99 \%$ of total variance and strong positively correlated with $\mathrm{B}, \mathrm{K}$ and moderate positively correlated by $\mathrm{NO}_{3}-\mathrm{N}$. $\mathrm{f}_{\mathrm{L} 24}$ formed $9.78 \%$ of total variance and positive correlated with $\mathrm{BOD}_{5}, \mathrm{pV}$; negative correlated with $\mathrm{DO}, \mathrm{f}_{\mathrm{L} 25}$ accounted for the total variance of $9.55 \%$ and was contributed by $\mathrm{pH}, \mathrm{SO}_{4}{ }^{2-}, \mathrm{Q}, \mathrm{E}-\mathrm{Coli} . \mathrm{f}_{\mathrm{L} 26}$ was represented by T-Coli with forming $9.13 \%$ of total variance.

FA/PCA and LRA were investigated together and $\mathrm{Ca} 99 \%$ and $\mathrm{SS}, \mathrm{T}, \mathrm{NH}_{4}-\mathrm{N}$, o- $\mathrm{PO}_{4}{ }^{3-}$ could explain the $\mathrm{f}_{\mathrm{L} 21}$. This factor represents soil structure which can be interpreted as a mineral component of the river. MRA was applied the data and $93 \%$ of parameters in $\mathrm{f}_{\mathrm{L} 22}$ were classified correctly by using COD and Fe. This factor could explain anthropogenic pollution such as industrial wastewater discharge. $\mathrm{B}^{3+}$, $\mathrm{K}^{+}$and $\mathrm{NO}_{3}-\mathrm{N}$ constituted $\mathrm{f}_{\mathrm{L} 23}$ which can be interpreted as agricultural activities such as irrigation water. $\mathrm{BOD}_{5}, \mathrm{pV}$ and $\mathrm{DO}$ explain the $\mathrm{f}_{\mathrm{L} 24}$ as domestic wastewater; $\mathrm{pH}, \mathrm{SO}_{4}{ }^{2-}, \mathrm{Q}$ and E-Coli explain the $\mathrm{f}_{\mathrm{L} 25}$ which describes the anthropogenic factor such as municipal wastewater discharge; T-Coli explains the $\mathrm{f}_{\mathrm{L} 26}$.

PCA of the 28 parameters constituted seven PCs explaining about $72.0 \%$ of the total variance at the 3BMA Station water quality data set for low flow period as seen in Table 4. $\mathrm{f}_{\mathrm{L} 31}$ has strong positive loadings on $\mathrm{TH}, \mathrm{EC}, \mathrm{M}-\mathrm{Al}, \mathrm{Ca}^{2+}, \mathrm{Na}^{+}, \mathrm{Cl}^{-}$ and negative loadings on $\mathrm{Q}$; moderate positive loadings on $\mathrm{NO}_{3}-\mathrm{N}, \mathrm{Mg}^{2+}, \mathrm{SO}_{4}^{2-}$ and moderate negative loadings on $\mathrm{Fe}$. It was formed $29.026 \%$ of total variance. $\mathrm{f}_{\mathrm{L} 32}$ accounting for $10.53 \%$ of total variance has strong positive loadings on $\mathrm{BOD}_{5}$, 


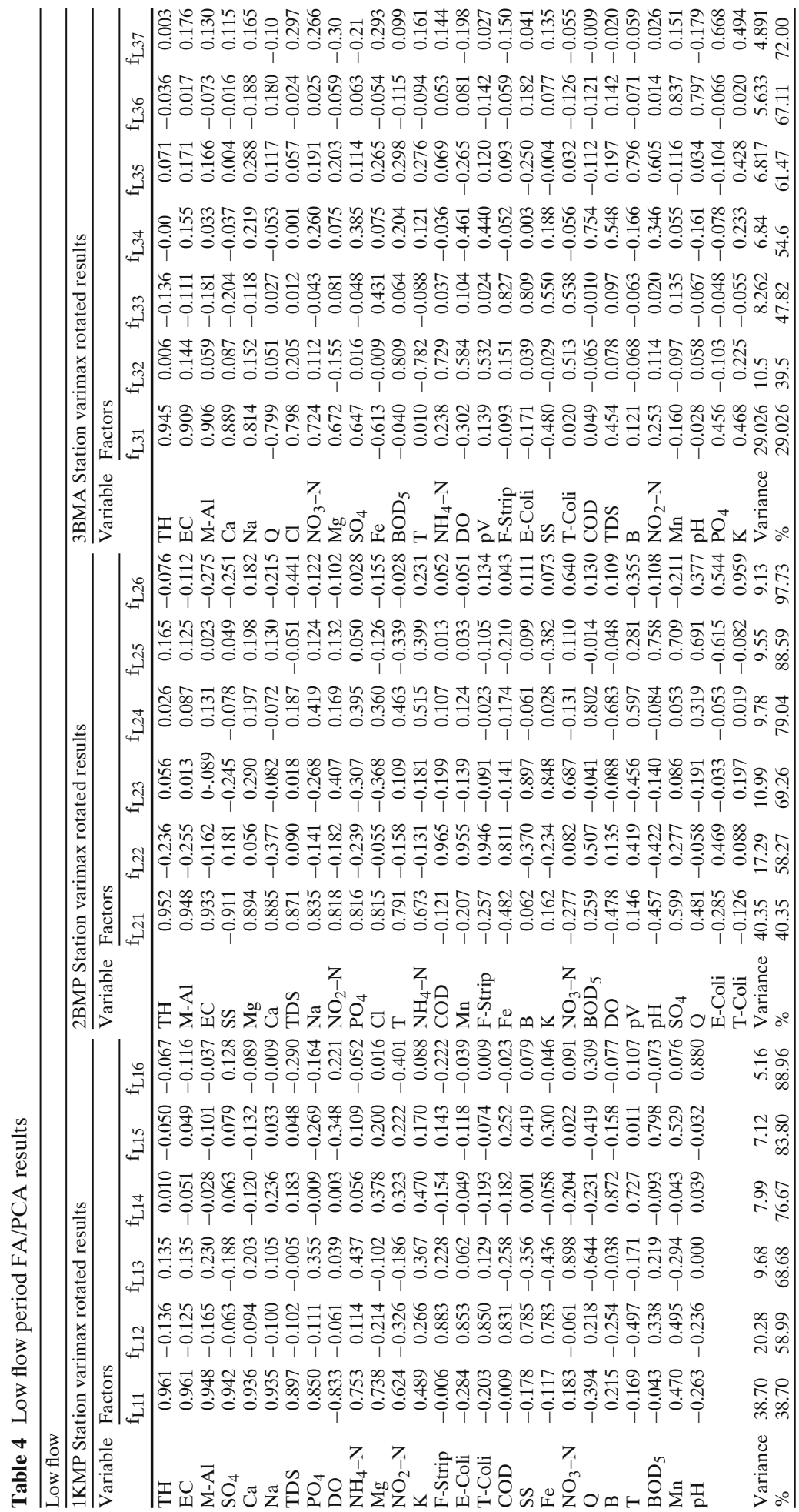




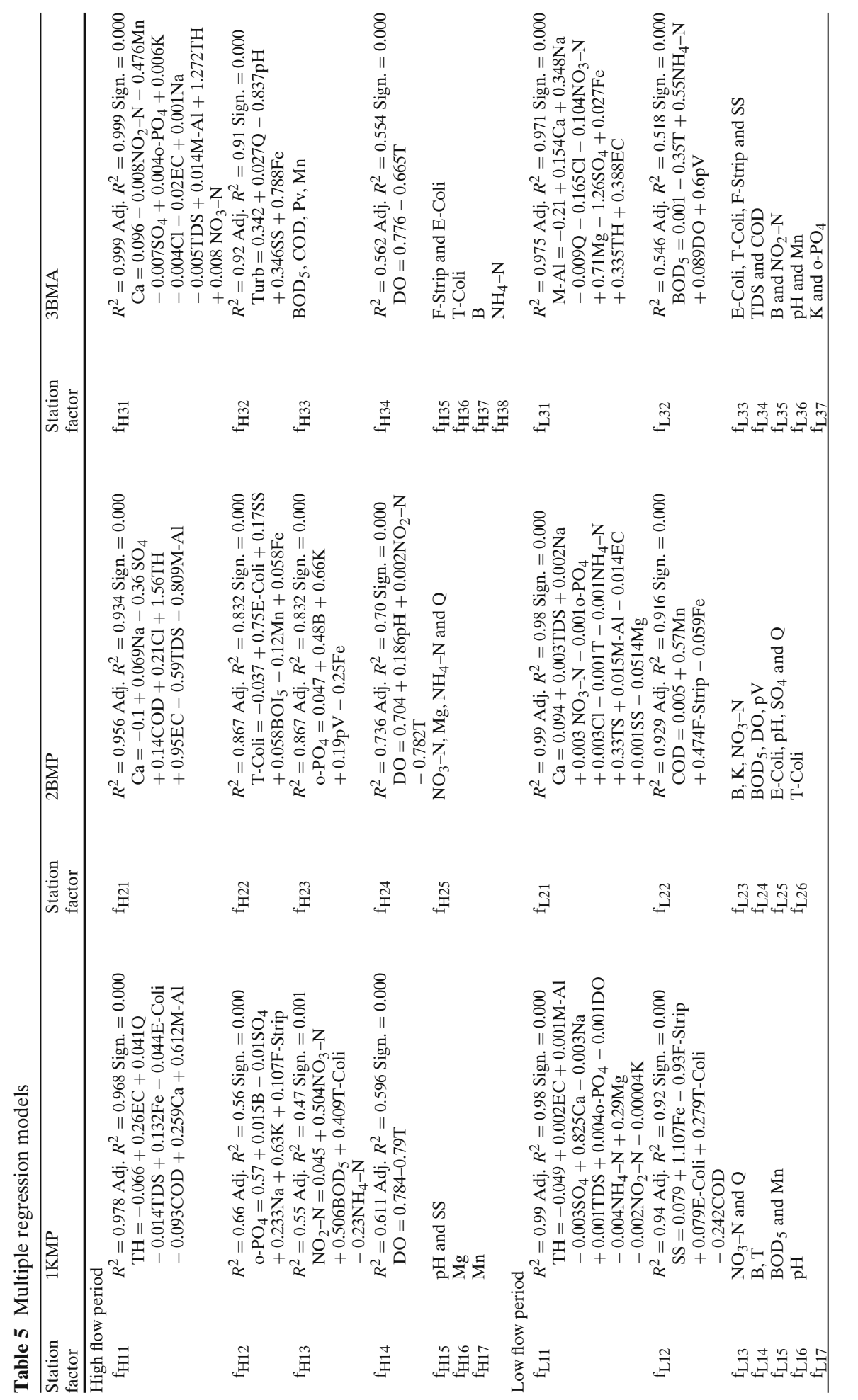


Table 6 Water quality parameters explained the factors

\begin{tabular}{|c|c|c|c|c|c|}
\hline $\begin{array}{l}\text { Station } \\
\text { factor }\end{array}$ & $1 \mathrm{KMP}$ & $\begin{array}{l}\text { Station } \\
\text { factor }\end{array}$ & 2BMP & $\begin{array}{l}\text { Station } \\
\text { factor }\end{array}$ & 3BMA \\
\hline \multicolumn{6}{|c|}{ High flow period } \\
\hline $\mathrm{f}_{\mathrm{H} 11}$ & $\begin{array}{l}98 \% \mathrm{TH} \text { and TDS, } \\
\text { COD, E-Coli }\end{array}$ & $\mathrm{f}_{\mathrm{H} 21}$ & $\begin{array}{l}95.6 \% \mathrm{Ca} \text { and } \\
\mathrm{COD}, \mathrm{Na}, \mathrm{TDS}\end{array}$ & $\mathrm{f}_{\mathrm{H} 31}$ & $\begin{array}{c}99 \% \mathrm{Ca} \text { and } \mathrm{SO}_{4}, \\
\mathrm{NO}_{2}-\mathrm{N}, \mathrm{o}-\mathrm{PO}_{4}\end{array}$ \\
\hline $\mathrm{f}_{\mathrm{H} 12}$ & $\begin{array}{c}66 \% \text { o- }-\mathrm{PO}_{4} \text { and } \\
\text { F-Strip, } \mathrm{SO}_{4}\end{array}$ & $\mathrm{f}_{\mathrm{H} 22}$ & $\begin{array}{l}86.7 \% \text { T-Coli } \\
\text { and SS }\end{array}$ & $\mathrm{f}_{\mathrm{H} 32}$ & $92 \%$ Turb. and Q \\
\hline $\mathrm{f}_{\mathrm{H} 13}$ & $\begin{array}{l}55 \% \mathrm{NO}_{2}-\mathrm{N} \\
\text { and } \mathrm{NH}_{4}-\mathrm{N}\end{array}$ & $\mathrm{f}_{\mathrm{H} 23}$ & $\begin{array}{c}55.5 \% \mathrm{o}-\mathrm{PO}_{4} \\
\text { and } \mathrm{Fe}, \mathrm{pV}\end{array}$ & $\mathrm{f}_{\mathrm{H} 33}$ & $\begin{array}{l}\mathrm{BOD}_{5}, \mathrm{COD}, \\
\mathrm{pV}, \mathrm{Mn}\end{array}$ \\
\hline $\mathrm{f}_{\mathrm{H} 14}$ & $61 \% \mathrm{DO}$ and $\mathrm{T}$ & $\mathrm{f}_{\mathrm{H} 24}$ & $\begin{array}{c}73.6 \% \mathrm{DO} \\
\text { and } \mathrm{pH}\end{array}$ & $\mathrm{f}_{\mathrm{H} 34}$ & $56 \% \mathrm{DO}$ and $\mathrm{T}$ \\
\hline $\mathrm{f}_{\mathrm{H} 15}$ & $\mathrm{pH}$ and $\mathrm{SS}$ & $\mathrm{f}_{\mathrm{H} 25}$ & $\begin{array}{l}\mathrm{NO}_{3}-\mathrm{N}, \mathrm{NH}_{4}-\mathrm{N}, \\
\mathrm{Mg} \text { and } \mathrm{Q}\end{array}$ & $\mathrm{f}_{\mathrm{H} 35}$ & F-Strip and E-Coli \\
\hline $\mathrm{f}_{\mathrm{H} 16}$ & $\mathrm{Mg}$ & & & $\mathrm{f}_{\mathrm{H} 36}$ & T-Coli \\
\hline \multirow[t]{2}{*}{$\mathrm{f}_{\mathrm{H} 17}$} & $\mathrm{Mn}$ & & & $\mathrm{f}_{\mathrm{H} 37}$ & B \\
\hline & & & & $\mathrm{f}_{\mathrm{H} 38}$ & $\mathrm{NH}_{4}-\mathrm{N}$ \\
\hline \multicolumn{6}{|c|}{ Low flow period } \\
\hline $\mathrm{f}_{\mathrm{L} 11}$ & $\begin{array}{l}99 \% \mathrm{TH} \text { and } \mathrm{CO}, \mathrm{K}, \\
\mathrm{NO}_{2}-\mathrm{N}, \mathrm{SO}_{4}\end{array}$ & $\mathrm{f}_{\mathrm{L} 21}$ & $\begin{array}{c}99 \% \mathrm{Ca} \text { and } \mathrm{SS}, \mathrm{T}, \\
\mathrm{NH}_{4}-\mathrm{N}, \mathrm{o}-\mathrm{PO}_{4}\end{array}$ & $\mathrm{f}_{\mathrm{L} 31}$ & $\begin{array}{l}97 \% \mathrm{M}-\mathrm{Al} \\
\text { and } \mathrm{Fe}, \mathrm{Q}\end{array}$ \\
\hline $\mathrm{f}_{\mathrm{L} 12}$ & $\begin{array}{l}94 \% \text { SS and } \\
\text { COD, F-Strip }\end{array}$ & $\mathrm{f}_{\mathrm{L} 22}$ & $93 \% \mathrm{COD}$ and $\mathrm{Fe}$ & $\mathrm{f}_{\mathrm{L} 32}$ & $\begin{array}{l}54 \% \mathrm{BOD}_{5} \\
\text { and } \mathrm{T}, \mathrm{CO}\end{array}$ \\
\hline $\mathrm{f}_{\mathrm{L} 13}$ & $\mathrm{NO}_{3}-\mathrm{N}$ and $\mathrm{Q}$ & $\mathrm{f}_{\mathrm{L} 23}$ & $\mathrm{~B}, \mathrm{~K}, \mathrm{NO}_{3}-\mathrm{N}$ & $\mathrm{f}_{\mathrm{L} 33}$ & $\begin{array}{l}\text { E-Coli, T-Coli, } \\
\text { F-Strip and SS }\end{array}$ \\
\hline $\mathrm{f}_{\mathrm{L} 14}$ & $\mathrm{~B}, \mathrm{~T}$ & $\mathrm{f}_{\mathrm{L} 24}$ & $\mathrm{BOD}_{5}, \mathrm{DO}, \mathrm{pV}$ & $\mathrm{f}_{\mathrm{L} 34}$ & TDS and COD \\
\hline $\mathrm{f}_{\mathrm{L} 15}$ & $\mathrm{BOD}_{5}$ and $\mathrm{Mn}$ & $\mathrm{f}_{\mathrm{L} 25}$ & $\begin{array}{l}\text { E-Coli, } \mathrm{pH}, \\
\mathrm{SO}_{4} \text { and } \mathrm{Q}\end{array}$ & $\mathrm{f}_{\mathrm{L} 35}$ & $\mathrm{~B}$ and $\mathrm{NO}_{2}-\mathrm{N}$ \\
\hline $\mathrm{f}_{\mathrm{L} 16}$ & $\mathrm{pH}$ & $\mathrm{f}_{\mathrm{L} 26}$ & T-Coli & $\begin{array}{l}f_{L 36} \\
f_{L 37}\end{array}$ & $\begin{array}{l}\mathrm{pH} \text { and } \mathrm{Mn} \\
\mathrm{K} \text { and o- } \mathrm{PO}_{4}\end{array}$ \\
\hline
\end{tabular}

$\mathrm{NH}_{4}-\mathrm{N}$ and strong negative loadings on $\mathrm{T}$; moderate positive loadings on DO, $\mathrm{pV}$ according to PCA results. $\mathrm{f}_{\mathrm{L} 33}$ accounting for $8.26 \%$ of total variance has strong positive loadings on F-Strip, E-Coli; moderate positive loadings on SS, T-Coli. Whereas, fourth, fifth, sixth and seventh factors accounted for the total variance of $6.84 \% ; 6.18 \% ; 5.63 \%$ and $4.89 \%$ were correlated with COD and TDS; $\mathrm{B}^{3+}$ and $\mathrm{NO}_{2}-$ $\mathrm{N} ; \mathrm{Mn}^{2+}$ and $\mathrm{pH} ; \mathrm{PO}_{4}^{3-}$ and $\mathrm{K}$ respectively.

FA/PCA and MRA were investigated together and $\mathrm{M}-\mathrm{Al} 97 \%$ and $\mathrm{Fe}^{2+}, \mathrm{Q}$ could explain the $\mathrm{f}_{\mathrm{L} 31}$. This factor represents soil structure which can be interpreted as a mineral component of the river. MRA was applied the data and $54 \%$ of parameters in $\mathrm{f}_{\mathrm{L} 32}$ were classified correctly by using $\mathrm{BOD}_{5}$, DO and $\mathrm{T}$. This factor could explain organic pollution such as municipal wastewater. F-Strip, E-Coli, SS and T-Coli constituted $\mathrm{f}_{\mathrm{L} 33}$ which can be interpreted as domestic wastewater and agricultural activities such as livestock wastes. COD and TDS could explain the $\mathrm{f}_{\mathrm{L} 34}$ as an anthropogenic factor such as industrial wastewater discharge; $\mathrm{B}^{3+}$ and $\mathrm{NO}_{2}-$ $\mathrm{N}$ explain the $\mathrm{f}_{\mathrm{L} 35}$ which describes the soil erosion and agricultural activities such as irrigation water; $\mathrm{Mn}^{2+}$ and $\mathrm{pH}$ explain the $\mathrm{f}_{\mathrm{L} 36}$ as industrial wastewater. $\mathrm{K}^{+}$and o- $\mathrm{PO}_{4}^{3-}$ explain the $\mathrm{f}_{\mathrm{L} 37}$ as domestic wastewater (Tables 5, 6, and 7). 
Table 7 Pollution sources according to factors

\begin{tabular}{|c|c|c|c|c|c|}
\hline $\begin{array}{l}\text { Station } \\
\text { factor }\end{array}$ & $1 \mathrm{KMP}$ & $\begin{array}{l}\text { Station } \\
\text { factor }\end{array}$ & 2BMP & $\begin{array}{l}\text { Station } \\
\text { factor }\end{array}$ & 3BMA \\
\hline \multicolumn{6}{|c|}{ High flow period } \\
\hline $\mathrm{f}_{\mathrm{H} 11}$ & Soil structure & $\mathrm{f}_{\mathrm{H} 21}$ & Soil structure & $\mathrm{f}_{\mathrm{H} 31}$ & $\begin{array}{l}\text { Soil structure- } \\
\text { agricultural }\end{array}$ \\
\hline $\mathrm{f}_{\mathrm{H} 12}$ & $\begin{array}{l}\text { Agricultural- } \\
\text { atmospheric }\end{array}$ & $\mathrm{f}_{\mathrm{H} 22}$ & $\begin{array}{l}\text { Municipal- } \\
\text { agricultural } \\
\text { (livestock) }\end{array}$ & $\mathrm{f}_{\mathrm{H} 32}$ & Soil erosion \\
\hline $\mathrm{f}_{\mathrm{H} 13}$ & $\begin{array}{l}\text { Domestic-dump } \\
\text { run-off }\end{array}$ & $\mathrm{f}_{\mathrm{H} 23}$ & Agricultural & $\mathrm{f}_{\mathrm{H} 33}$ & Industrial \\
\hline $\mathrm{f}_{\mathrm{H} 14}$ & Seasonal & $\mathrm{f}_{\mathrm{H} 24}$ & Industrial & $\mathrm{f}_{\mathrm{H} 34}$ & Seasonal \\
\hline $\mathrm{f}_{\mathrm{H} 15}$ & Industrial & $\mathrm{f}_{\mathrm{H} 25}$ & $\begin{array}{l}\text { Agricultural- } \\
\text { atmospheric }\end{array}$ & $\mathrm{f}_{\mathrm{H} 35}$ & Domestic \\
\hline $\mathrm{f}_{\mathrm{H} 16}$ & $\mathrm{Mg}$ & & & $\mathrm{f}_{\mathrm{H} 36}$ & T-Coli \\
\hline $\mathrm{f}_{\mathrm{H} 17}$ & $\mathrm{Mn}$ & & & $\mathrm{f}_{\mathrm{H} 37}$ & B \\
\hline & & & & $\mathrm{f}_{\mathrm{H} 38}$ & $\mathrm{NH}_{4}-\mathrm{N}$ \\
\hline \multicolumn{6}{|c|}{ Low flow period } \\
\hline $\mathrm{f}_{\mathrm{L} 11}$ & Soil structure & $\mathrm{f}_{\mathrm{L} 21}$ & $\begin{array}{l}\text { Soil structure- } \\
\text { soil erosion }\end{array}$ & $\mathrm{f}_{\mathrm{L} 31}$ & Soil structure \\
\hline $\mathrm{f}_{\mathrm{L} 12}$ & $\begin{array}{l}\text { Municipal- } \\
\text { agricultural } \\
\text { (livestock) }\end{array}$ & $\mathrm{f}_{\mathrm{L} 22}$ & Industrial & $\mathrm{f}_{\mathrm{L} 32}$ & Municipal \\
\hline $\mathrm{f}_{\mathrm{L} 13}$ & $\begin{array}{l}\text { Agricultural } \\
\text { (irrigation } \\
\text { water) }\end{array}$ & $\mathrm{f}_{\mathrm{L} 23}$ & $\begin{array}{l}\text { Agricultural } \\
\quad \text { (irrigation } \\
\text { water) }\end{array}$ & $\mathrm{f}_{\mathrm{L} 33}$ & $\begin{array}{l}\text { Domestic- } \\
\text { agricultural } \\
\text { (livestock) }\end{array}$ \\
\hline $\mathrm{f}_{\mathrm{L} 14}$ & $\begin{array}{l}\text { Soil erosion- } \\
\text { seasonal }\end{array}$ & $\mathrm{f}_{\mathrm{L} 24}$ & Domestic & $\mathrm{f}_{\mathrm{L} 34}$ & Industrial \\
\hline $\mathrm{f}_{\mathrm{L} 15}$ & Domestic & $\mathrm{f}_{\mathrm{L} 25}$ & Municipal & $\mathrm{f}_{\mathrm{L} 35}$ & $\begin{array}{l}\text { Soil erosion- } \\
\text { agricultural } \\
\text { (irrigation } \\
\text { water) }\end{array}$ \\
\hline $\mathrm{f}_{\mathrm{L} 16}$ & $\mathrm{pH}$ & $\mathrm{f}_{\mathrm{L} 26}$ & T-Coli & $\begin{array}{l}f_{L 36} \\
f_{L 37}\end{array}$ & $\begin{array}{l}\text { Industrial } \\
\text { Domestic }\end{array}$ \\
\hline
\end{tabular}

Table 8 Temporal variation discriminant function coefficients

\begin{tabular}{lrr}
\hline & \multicolumn{2}{l}{ Period } \\
\cline { 2 - 3 } & High flow & Low flow \\
\hline $\mathrm{DO}$ & 14.098 & 9.993 \\
$\mathrm{EC}$ & 1.818 & -15.808 \\
$\mathrm{~F}-$ Strip & 4.172 & 0.362 \\
$\mathrm{~K}$ & 4.197 & 10.421 \\
$\mathrm{Mal}$ & 6.983 & 13.308 \\
$\mathrm{Mn}$ & 8.002 & 3.587 \\
$\mathrm{NH}_{4}-\mathrm{N}$ & 11.035 & 7.205 \\
$\mathrm{NO}_{3}-\mathrm{N}$ & 0.123 & 3.135 \\
$\mathrm{pH}$ & 6.748 & 3.213 \\
$\mathrm{SO}_{4}$ & -5.980 & -0.118 \\
$\mathrm{TDS}$ & 6.405 & 14.786 \\
(Constant) & -12.997 & -10.422 \\
\hline
\end{tabular}


Table 9 Temporal variation classification matrix for discriminant analysis

\begin{tabular}{llcc}
\hline Stepwise DA mode & & \\
\hline \% Correct & \multicolumn{2}{l}{ Period assigned by DA } \\
\cline { 2 - 4 } & & High flow & Low flow \\
\hline High flow & 89.5 & 145 & 37 \\
Low flow & 74.7 & 17 & 109 \\
Total & 82.5 & 162 & 146 \\
\hline
\end{tabular}

\subsection{Discriminant Functions}

Temporal variations in water quality were investigated through DA. Temporal DA was performed on standardized data by dividing the data set into two period groups (high-low flow period) at each stations. Discriminant functions obtained from stepwise mode of DA are shown in Table 8. Variables were added step by step in stepwise mode with the more significant until no significant changes and results were obtained. Stepwise mode discriminant functions using 11 discriminant variables presented the classification matrices separating $82.5 \%$ cases correctly as seen in Table 9. Stepwise DA shows that DO, EC, F-Strip, $\mathrm{K}^{+}, \mathrm{M}-\mathrm{Al}, \mathrm{Mn}^{2+}, \mathrm{NH}_{4}-\mathrm{N}, \mathrm{NO}_{3} \mathrm{~N}, \mathrm{pH}$, $\mathrm{SO}_{4}^{2-}$, TDS are the most significant parameters to discriminate between the two different periods. These parameters are responsible for the temporal variations in water quality.

$$
\begin{aligned}
z_{T}= & \beta_{0}+\beta_{1} \cdot D O+\beta_{2} \cdot E C+\beta_{3} \cdot F-S t r i p+\beta_{4} \cdot K+\beta_{5} \cdot M-A l \\
& +\beta_{6} \cdot M n+\beta_{7} \cdot N H_{4}-N+\beta_{8} \cdot N O_{3} N+\beta \cdot \mathrm{pH}+\beta_{10} \cdot \mathrm{SO}_{4}+\beta_{11} \cdot \mathrm{TDS}
\end{aligned}
$$

Spatial DA was performed on standardized data by dividing the data set into five site groups (1KMP, 2BMP, 3BMA, 4AC, 5US). Discriminant functions obtained from stepwise mode of DA are shown in Table 8 . Variables were added step by

\begin{tabular}{|c|c|c|c|c|c|}
\hline \multicolumn{6}{|l|}{ Stations } \\
\hline & $1 \mathrm{KMP}$ & 2BMP & 3BMA & $4 \mathrm{AC}$ & $5 \mathrm{US}$ \\
\hline $\mathrm{BOD}_{5}$ & 12.233 & 19.294 & 21.947 & 11.239 & 3.466 \\
\hline $\mathrm{Ca}$ & 94.876 & 134.563 & 71.048 & 174.739 & 100.029 \\
\hline $\mathrm{DO}$ & 90.623 & 73.136 & 110.210 & 90.354 & 91.382 \\
\hline $\mathrm{EC}$ & -17.169 & -5.531 & 17.836 & 46.814 & 67.959 \\
\hline E-Coli & 7.813 & -2.860 & 7.384 & -1.459 & 2.608 \\
\hline $\mathrm{M}-\mathrm{Al}$ & 37.030 & -5.877 & 61.332 & -34.262 & 23.901 \\
\hline $\mathrm{Mg}$ & 45.316 & 65.452 & 26.595 & 83.391 & 46.275 \\
\hline $\mathrm{Mn}$ & 26.075 & 14.135 & 24.839 & 17.258 & 21.134 \\
\hline $\mathrm{Na}$ & 5.143 & -2.516 & 8.682 & 14.858 & 5.428 \\
\hline $\mathrm{NH}_{4}-\mathrm{N}$ & 23.066 & 17.531 & 21.523 & 35.615 & 22.453 \\
\hline $\mathrm{NO}_{3}-\mathrm{N}$ & 23.853 & 27.381 & 7.040 & 24.608 & 18.037 \\
\hline $\mathrm{pH}$ & 14.842 & 27.167 & 0.139 & 20.641 & 14.781 \\
\hline $\mathrm{SO}_{4}$ & -2.305 & 8.104 & -19.662 & -24.611 & -7.051 \\
\hline $\mathrm{T}$ & 60.526 & 52.130 & 69.626 & 60.003 & 57.131 \\
\hline $\mathrm{TH}$ & -125.494 & -152.035 & -126.528 & -213.181 & -186.061 \\
\hline (Constant) & -66.974 & -60.726 & -78.843 & -75.190 & -68.376 \\
\hline
\end{tabular}

Table 10 Spatial variation discriminant function coefficients 
Table 11 Spatial variation classification matrix for discriminant analysis

\begin{tabular}{llrrrrr}
\hline \multicolumn{7}{l}{ Stepwise DA mode } \\
\hline \% Correct & \multicolumn{5}{l}{ Period assigned by DA } \\
\cline { 2 - 7 } & & 1KMP & 2BMP & 3BMA & 4AC & 5US \\
\hline 1KMP & 91.7 & 44 & 2 & 2 & 1 & 3 \\
2BMP & 77.1 & 2 & 37 & 1 & 1 & 1 \\
3BMA & 97.0 & 0 & 0 & 128 & 0 & 0 \\
4AC & 83.3 & 1 & 9 & 1 & 40 & 0 \\
5US & 91.7 & 1 & 0 & 0 & 6 & 44 \\
Total & 90.4 & 48 & 48 & 132 & 48 & 48 \\
\hline
\end{tabular}

step in stepwise mode with the more significant until no significant changes and results were obtained. Stepwise mode discriminant functions using 14 discriminant variables presented the classification matrices separating $90,4 \%$ cases correctly as seen in Table 9. Stepwise DA shows that $\mathrm{BOD}_{5}, \mathrm{Ca}^{2+}$, DO, E-Coli, M-Al, $\mathrm{Mg}^{2+}$, $\mathrm{Mn}^{2+}, \mathrm{Na}^{+}, \mathrm{NH}_{4}-\mathrm{N}, \mathrm{NO}_{3} \mathrm{~N}, \mathrm{pH}, \mathrm{SO}_{4}^{2-}, \mathrm{T}, \mathrm{TH}$ are the most significant parameters to discriminate between the two different periods. These parameters are responsible for the spatial variations in water quality (Tables 10 and 11).

$$
\begin{aligned}
z_{S}= & \beta_{0}+\beta_{1} \cdot \mathrm{BOI}_{5}+\beta_{2} \cdot \mathrm{Ca}+\beta_{3} \cdot \mathrm{Ç} O+\beta_{4} \cdot E C+\beta_{5} \cdot \text { E-Coli }+\beta_{6} \cdot M-A l \\
& +\beta_{7} \cdot M g+\beta_{8} \cdot M n+\beta_{9} \cdot N a+\beta_{10} \cdot N H 4-N+\beta_{11} \cdot N O_{3} N+\beta_{12} \cdot p H \\
& +\beta_{13} \cdot S O_{4}+\beta_{14} \cdot T+\beta_{15} \cdot T S
\end{aligned}
$$

Classification function coefficients for each groups of temporal and spatial DA are given in Tables 8 and 10 respectively. Discriminant coefficients are converted to $\mathrm{z}$ scores to eliminate scaling differences among the discriminator variables. These functions can be used to calculate real estimate model ( $\mathrm{z}$ scores) which may be used for classification of new samples. Among $\mathrm{z}$ scores of new sample measurement, the $\mathrm{z}$ score which is largest than zero will give us the group which its belongs to.

\section{Conclusions}

In this study, different multivariate statistical methods were used to investigate the Melen River complex data set obtained during 11 years. FA/PCA, MRA and DA applied the each data set of sample points and results were investigated. FA/PCA identified factors which are responsible for the data structure of each station at high and low flow periods. MRA identified the important and effective parameters according to relation between parameters in factors First factors for each station are explained with soil structure which comes from the dissolution of soil-rock by weathering. All stations are affected the agricultural and industrial pollution due to the intensive agricultural activities such as fertilizer, livestock waste and industrial areas near the river channel in basin. Especially at low flow period, impact of agricultural irrigation water is shown clearly. At rural areas and some cities in basin have no treatment plant for domestic and municipal wastewater. Septic tanks using for domestic wastewater and direct discharge of municipal wastewater are determined at all stations. Wild dump of Düzce city contribution is seen at 1KMP station. DA gave the best results both temporal and spatial analysis. It allowed a determining an 
indicator parameters responsible for large variations in water quality. DA showed that the most significant parameters for temporal variations are DO, EC, F-Strip, $\mathrm{K}^{+}, \mathrm{M}-\mathrm{Al}, \mathrm{Mn}^{2+}, \mathrm{NH}_{4}-\mathrm{N}, \mathrm{NO}_{3}-\mathrm{N}, \mathrm{pH}, \mathrm{SO}_{4}^{2-}$, TDS and for spatial variations are $\mathrm{BOD}_{5}, \mathrm{Ca}^{2+}$, DO, E-Coli, M-Al, $\mathrm{Mg}^{2+}, \mathrm{Mn}^{2+}, \mathrm{Na}^{+}, \mathrm{NH}_{4}-\mathrm{N}, \mathrm{NO}_{3}-\mathrm{N}, \mathrm{pH}, \mathrm{SO}_{4}^{2-}, \mathrm{T}$, $\mathrm{TH}$. A few indicator parameters responsible for the spatial and temporal variations are found out by using DA. Melen River water quality assessment, pollution sources and parameters responsible for the spatial-temporal variations can be identified. And so this study provides the reduction in dimensionality of large data set. In this connection, less data set in monitoring program can be used for identification of water quality because of the measurement cost.

Acknowledgements This study was performed by using water quality data obtained from monitoring programs of Government Water Association in Ankara, Turkey.

\section{References}

Amiri BJ, Nakane K (2009) Modeling the linkage between riverwater quality and landscape metrics in the Chugoku District of Japan. Water Resour Manag 23:931-956

APHA-AWWA-WPCF (1999) In standard methods for the examination of water and wastewater, 20th edn. American Public Health Association, Washington

Boyacıoğlu H, Boyacıoğlu H (2006) Water pollution sources assessment by multivariate statistical methods in the Tahtali Basin, Turkey. Environ Geol 54:275-282

Brumelis G, Lapina L, Nikodemus O, Tabors G (2000) Use of an artificial model of monitoring data to aid interpretation of principal component analysis. Environ Model Softw 15:755-763

Crowther J, Kay D, Wyer MD (2001) Relationships between microbial water quality and environmental conditions in coastal recreational waters: the Fylde Coast, UK. Water Res 35(17):40294038

Dixon W, Chiswell B (1996) Review of aquatic monitoring program design. Water Res 30:1935-1948

Dogan E, Sengorur B, Koklu R (2009) Modeling biological oxygen demand of the Melen River in Turkey using an artificial neural network technique. J Environ Manag 90:1229-1235

Düzce Governorship Environment and Forest Directorship (2007) Düzce Environment State Report, Düzce

Freund RJ, Wilson WJ (1998) Regression analysis-statistical modeling of a response variable. Academic Press

Kannel PR, Lee S, Kanel SR, Khan SP (2007) Chemometric application in classification and assessment of monitoring locations of an urban river system. Anal Chim Acta 582:390-399

Kottı ME, Vlessıdıs GA, Thanasoulıas NC, Evmırıdıs NP (2005) Assessment of river water quality in Northwestern Greece. Water Resour Manag 19:77-94

Kowalkowski T, Zbytniewski R, Szpejna J, Buszewski B (2006) Application of chemometrics in river water classification. Water Res 40:744-752

Liu CW, Lin KH, Kuo YM (2003) Application of factor analysis in the assessment of groundwater quality in a Blackfoot disease area in Taiwan. Sci Total Environ 313:77-89

Maillard P, Santos NAP (2008) A spatial-statistical approach for modeling the effect of non-point source pollution on different water quality parameters in the Velhas River Watershed-Brazil. J Environ Manag 86:158-170

Mainstone CP, Parr W (2002) Phosphorus in rivers-ecology and management. Sci Total Environ 282-283:25-47

Mallin MA, Williams KE, Esham EC, Lowe RP (2000) Effect of human development on bacteriological water quality in coastal watersheds. Ecol Appl 10(4):1047-1056

Ouyang Y (2005) Evaluation of river water quality monitoring stations by principal component analysis. Water Res 39:2621-2635

Ouyang Y, Nkedi-Kizza P, Wu QT, Shinde D, Huang CH (2006) Assessment of seasonal variations in surface water quality. Water Res 40:3800-3810

Panda UC, Sundaray SK, Rath P, Nayak BB, Bhatta D (2006) Application of factor and cluster analysis for characterization of river and estuarine water systems - a case study: Mahanadi River (India). J Hydrol 331:434-445 
Pekey H, Karakaş D, Bakoğlu M (2004) Source apportionment of trace metals in surface waters of a polluted stream using multivariate statistical analyses. Mar Pollut Bull 49:809-818

Sengörür B, İsa D (2001) Sakarya Nehri'ne Ait Su Kalite Gözlemlerinin Faktör Analizi. Turk J Eng Environ Sci, Tübitak 25:415-425

Shrestha S, Kazama F (2007) Assessment of surface water quality using multivariate statistical techniques: a case study of the Fuji River Basin, Japan. Environ Model Softw 22(4):464-475

Simeonov V, Stratis JA, Samara C, Zachariadis G, Voutsa D, Anthemidis A, Sofonioub M, Kouimtzis TH (2003) Assessment of the surface water quality in Northern Greece. Water Res 37:4119-4124

Singh KP, Malik A, Sinha S (2005) Water quality assessment and apportionment of pollution sources of Gomti River (India) using multivariate statistical techniques-a case study. Anal Chim Acta 538:355-374

Singh KP, Malik A, Mohan D, Sinha S (2004) Multivariate statistical techniques for the evaluation of spatial and temporal variations in water quality of Gomti River (India) — a case study. Water Res 38:3980-3992

Sliva L, Williams DD (2001) Buffer zone versus whole catchment approaches to studying land use impact on river water quality. Water Res 35(14):3462-3472

Tinsley EAH, Brown SD (2000) Handbook of applied multivariate statistics and mathematical modeling. Academic, San Diego

Vega M, Pardo R, Barrado E, Deban L (1998) Assessment of seasonal and polluting effects on the quality of river water by exploratory data analysis. Water Res 32(12):35

Wang X (2001) Integrating water-quality management and land-use planning in a watershed context. J Environ Manag 61:25-36 